\title{
Hypoalbuminemia: an underestimated, vital characteristic of hospitalized COVID-19 positive patients?
}

\author{
Giuliano Ramadori \\ Clinic for Gastroenterology and Endocrinology, University Medical Center Göttingen, Göttingen 37075, Germany.
}

Correspondence to: Dr. Giuliano Ramadori, Clinic for Gastroenterology and Endocrinology, University Medical Center Göttingen, Göttingen 37075, Germany. E-mail: giulianoramadori@gmail.com

\begin{abstract}
How to cite this article: Ramadori G. Hypoalbuminemia: an underestimated, vital characteristic of hospitalized COVID-19 positive patients? Hepatoma Res 2020;6:28. http://dx.doi.org/10.20517/2394-5079.2020.43
\end{abstract}

Received: 21 Apr 2020 First Decision: 6 May 2020 Revised: 7 May 2020 Accepted: 13 May 2020 Published: 3 Jun 2020

Science Editor: Guang-Wen Cao Copy Editor: Jing-Wen Zhang Production Editor: Tian Zhang

\begin{abstract}
The COVID-19 pandemic has led to the greatest worldwide health crisis in decades. The number of infected patients with severe SARS-CoV-2 (COVID-19) disease has overwhelmed the capacity of almost all health care systems around world. Hypoalbuminemia has now been reported in patients with severe disease seeking help in the emergency room because of COVID-19 infection. In the past, hypoalbuminemia was considered to be a negative prognostic marker, not only in patients with chronic liver disease, but also in patients with SARS and MERS infections. Albumin is the major serum protein synthesized by the liver. A low serum albumin level is an ominous clinical sign. Introduction of amino acids to a patient's diet is of fundamental importance to hepatic albumin synthesis in different clinical situations. This highlights the importance of nutritional support during the early phases of COVID-19-infection. Furthermore, albumin synthesis in the hepatocyte is downregulated at a pretranslational level by the direct interaction of the major acute-phase cytokines which are released into the circulation during the cytokine "storm" induced by the viral effects on the lungs. Both mechanisms contribute to severe hypoalbuminemia which, combined with massive fluid losses due to the fever, is responsible for severe hypovolemia and shock commonly observed in patients with COVID-19 in critical care settings.
\end{abstract}

Keywords: Severe acute respiratory syndrome cornonavirus 2, SARS-CoV-2, COVID-19, albumin synthesis, nutrition, acute-phase reaction, cytokines, liver, extrahepatic organs

\section{COVID-19 INFECTION AND THE CLINICAL RELEVANCE OF HYPOALBUMINEMIA}

Severe acute respiratory syndrome, cornonavirus 2 (SARS-CoV-2), formally CoV-19, is a recently recognized RNA-virus which belongs to a larger family of pathogenic human viruses. Severe acute respiratory syndrome

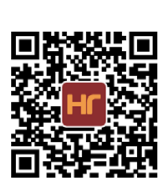


cornonavirus-1 and Middle East respiratory syndrome coronavirus caused primarily pulmonary diseases. HuCoV 229E, 0C43, NL63 and HKU1 are mainly responsible for the common cold, but can also cause lethal nonspecific pneumonias ${ }^{[1]}$. However, SARS-CoV-2 has a wide range of clinical presentations, with acute respiratory distress syndrome being the often fatal pulmonary complication ${ }^{[2-4]}$.

Most of the publications reporting clinical characteristics for patients with SARS-CoV-2-infection originate from China, many from the city of Wuhan. These publications are descriptive retrospective case series about patients hospitalized with the virus or who died in intensive care units (ICU) ${ }^{[5,6]}$. The symptoms reported mainly concern the reason for hospitalisation. The spectrum of all symptoms, and key timings from when patients first felt unwell is less well reported ${ }^{[7,8]}$. In fact, far less is known about the symptomatology at the time of first appearance of the disease in hospitalized patients and in infected persons who remained at home, and who may had even died there.

Parameters indicating liver damage include prothrombin time, serum transaminase and bilirubin levels, acute-phase response markers such as leukocyte count. C-reactive protein, procalcitonin, and several serum cytokine levels have been reported in patients with SARS-CoV-2, together with changes in serum albumin levels ${ }^{[2-5,9,10]}$. Previous experiences in patients with SARS or MERS suggested that hypoalbuminemia, lymphopenia, a serum CRP level greater than $4 \mathrm{mg} / \mathrm{dL}$, plus elevated lactate dehydrogenase on hospital admission were predictive for pneumonia progressing to respiratory failure ${ }^{[11-14]}$. Low serum albumin levels have now been found to be an important predictor of progression to severe disease and increased mortality in hospitalised SARS-CoV-2 positive patients of older age ${ }^{[15,16]}$.

\section{PATHOPHYSIOLOGICAL ASPECTS OF HYPOALBUMINEMIA AND CLINICAL RELEVANCE OF ALBUMIN INFUSION}

Albumin is a single chain protein with a molecular weight of $66 \mathrm{kDa}$ made of 585 amino acids which represents more than $50 \%$ of the serum proteins and represents an important component of interstitial fluid. The albumin fraction was first separated from the other components of the plasma in 1944 by Edwin $\operatorname{Cohn}^{[17]}$, who also appreciated its strong oncotic properties. This characteristic of albumin was also confirmed by Scatchard et al. ${ }^{[18]}$ in 1944 . Serum albumin levels are used as useful surrogates of liver function ${ }^{[19]}$. Soon after the fractionation studies, intravenous albumin administration was performed in patients with advanced liver disease. This was done in the United States during the $19400^{\text {' }}{ }^{[21,22]}$ and also in the United Kingdom at the beginning of the 1960's by Wilkinson and Sherlock et al. ${ }^{[2]}$.

The beneficial effect of prolonged administration was first demonstrated in a clinical trial by the group of Paolo Gentilini in Florence ${ }^{[23]}$, and more recently by Caraceni et al ${ }^{[24]}$ in Bologna.

The positive diuretic effect of albumin infusion in three patients with liver cirrhosis was published by Patek et al. ${ }^{[25]}$. This finding was subsequently corroborated in a group of ten patients ${ }^{[26,27]}$, showing that albumin infusion in patients with liver cirrhosis and ascites (without spontaneous bacterial peritonitis) increased sodium excretion in the urine, and led to weight reduction and a reduction in diuretics required.

It was shown that repeated daily intravenous administration of albumin was able to avoid the requirement for transjugular stent placement into the portal tract trough the hepatic vein (TIPS) ${ }^{[28]}$. A similar experience, in a larger patient numbers, was published by Trotter et al. ${ }^{[29]}$.

The positive effects of albumin infusion in cirrhotic patients with low levels of serum albumin was shown by Bajaj et al. ${ }^{[30]}$ who observed a normalisation in serum sodium concentration in patients with liver cirrhosis and hyponatriemia. Infusion of intravenous albumin solution in decompensated cirrhotic patients was also able to reduce encephalopathic episodes and associated mortality ${ }^{[31]}$. 

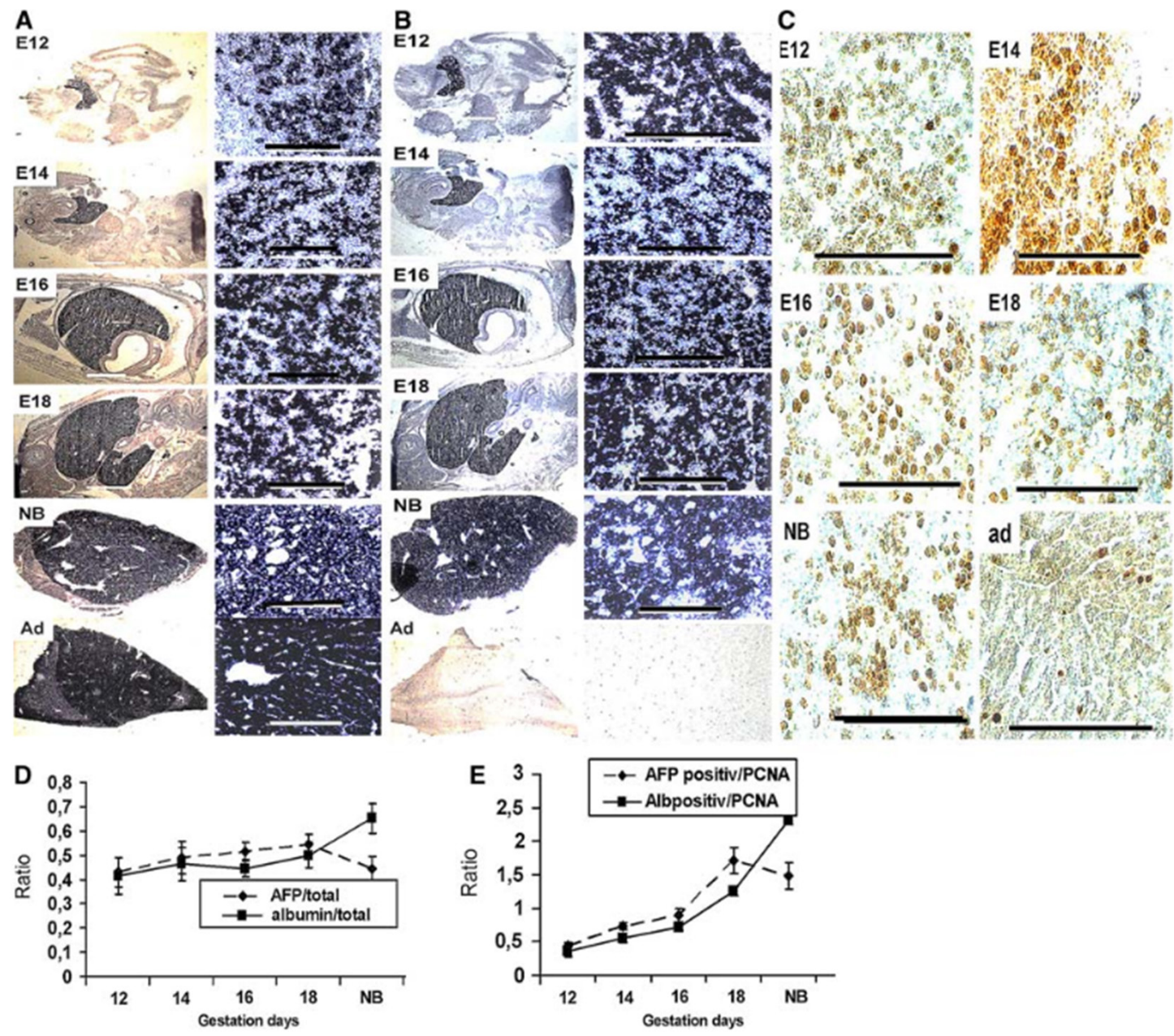

Fig. 5 Albumin- (A) and AFP- (B) mRNA-expression in developing liver assessed by in situ hybridization using DIG-labeled antisense RNA probes (Original magnification 50×; 200×, Bars $=100 \mu \mathrm{m}$ ). $($ C) Proliferation of hepatoblasts estimated by the number of cells positively stained for proliferating cell nuclear antigen (PCNA) in developing liver. Immunohistochemical reaction was detected by peroxidase-labeled secondary antibody (Original magnification $400 \times$, bars $=100 \mu \mathrm{m}$ ). (D) The ratio of albumin- and AFP-expressing cells

to total cells and $(\mathbf{E})$ the ratio of albumin- and AFP-expressing cells to $\mathrm{PCNA}^{+}$cells during liver development. Albumin- and AFP-positive cells were identified by in situ hybridization, and PCNA-positive cells by immunohistochemical staining. The positive cells were counted under microscope using a shaded ocular, and by application of Image J software. Error bars represent S.E.M., $n=3$. The significance $(P<0.05)$ was analyzed by ANOVA

Figure 1. Panel $A$ shows the results of in-situ-hybridisation analysis performed in slices of embrional liver at different stages of developement in NB and Ad rats. The intensity of the reaction demonstrates an abundance of albumin-specific mRNA. NB: newborn; Ad: adult. Histochem Cel/ Bio/ 2007;128:431-43. (reprinted with permission) ${ }^{[37]}$

The prognostic importance of serum albumin levels in patients with liver disease is demonstrated by the inclusion of this parameter in the Child-Turcotte-Pugh score, used to assess the prognosis of chronic liver disease, mainly cirrhosis. This score was introduced by surgeons in $1963^{[32]}$.

In addition, serum albumin level is a key nutritional parameter used to estimate the grade of malnutrition, and to predict survival in patients with liver cirrhosis. Malnutrition is an independent risk factor for transplantation, and improves the prognostic value of the Child-Turcotte-Pugh score, reported by Alberino et al. ${ }^{[33]}$.

While administration of albumin in patients with advanced liver disease and hypoalbuminemia is now a standard therapy, albumin administration in critically ill patients with or without liver disease in the ICU is controversial $^{[34-36]}$. 


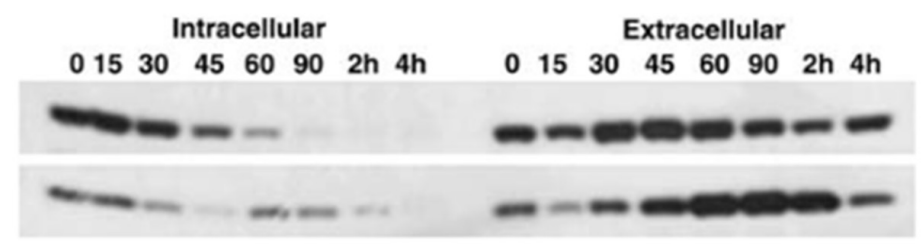

Fig. 4 Kinetics for albumin synthesis and secretion in hepatoblasts (E14) and adult hepatocytes estimated by pulse chase experiment. The secretion speed in E14 hepatoblasts (upper panel) was comparable with that of the adult hepatocytes (lower panel). At $60 \mathrm{~min}$ the apparent increase of labeled albumin protein in the intracellular pool of adult hepatocytes is due to the contamination of the extracellular pool, which dramatically increased at this time point

Figure 2. Autoradiograph of a SDS-PAGE-analysis of immunoprecipitates from cell culture supernatants (hepatoblasts and hepatocytes). Radioactively labelled albumin was immunoprecipitated with a specific antibody. The strong speed of the release of the newly synthesized protein is an explanation for the difficulty to detect albumin (as a protein) in the liver sections by using immunostaining techniques. Histochem Cell Biol 2007;128:431-43. (reprinted with permission) ${ }^{[37]}$

The liver is the sole source of serum albumin ${ }^{[37]}$ [Figures 1 and 2] which represents more than $50 \%$ of all proteins synthesized in the liver. Under normal conditions albumin synthesis in the hepatocytes is regulated by the amount of proteins reaching the intestine after each meal, and the amount of amino acids transported into the liver through the portal system.

During fasting, reduced albumin synthesis is due to a reduced uptake of amino acids into the hepatocytes ${ }^{[38]}$, which may be in part compensated by using amino acids from muscle proteins.

During acute phase situations, characterised by tissue damage induced by different insults such as trauma, bacterial infection, or viral infections such as SARS-CoV-2, the defence mechanisms of the body concentrate on eliminating the aggressive agent at the site of tissue entry and/or the damaged tissue. The main systemic reactions during the COVID-19 illness are fever, weakness and loss of appetite. In addition vomiting, diarrhea and abdominal discomfort ${ }^{[39]}$, which may be accompanied by loss of taste ${ }^{[40]}$ and loss of smell $(\text { anosmia })^{[41,42]}$, may be also be present. At the beginning of the illness a dry cough and sometimes dyspnoea may be present. The systemic defence reaction may last for a few days and the consequences may not be clinically noted if the person continues to stay home and recovers promptly. If the symptoms last for a week or longer, two major consequences have to be considered: (1) severe fluid losses leading to dehydration and ultimately hypovolaemic shock; (2) reduction in caloric intake which worsens symptoms of weakness, and accelerates a rapid loss in body weight ${ }^{[43]}$.

These changes may be aggravated by the simultaneous intake of antihypertensive medication, including diuretics, as might be encountered in older patients and/or those patients with multiple comorbidities ${ }^{[44]}$.

The systemic reaction, a major component of body defence strategy, is induced by different cytokines that originate the main site of injury, e.g., the lungs. The so called "major acute-phase mediators" are Interleukin-6, Interleukin-1, TNF-alpha, and IFN-gamma, which are all synthesized in different amounts, depending on the quality (organ and damaging agent) and the quantity of tissue damage.

The acute phase cytokines are responsible for the central regulation of body temperature ${ }^{[45]}$, reduction in appetite, and associated adynamia and mental confusion ${ }^{[46]}$.

The reduction of appetite (anorexia) on the one hand, and abdominal discomfort on the other, can also be attributed to the direct action of the cytokines on the intestinal neurons, with alterations in the mobility 
A

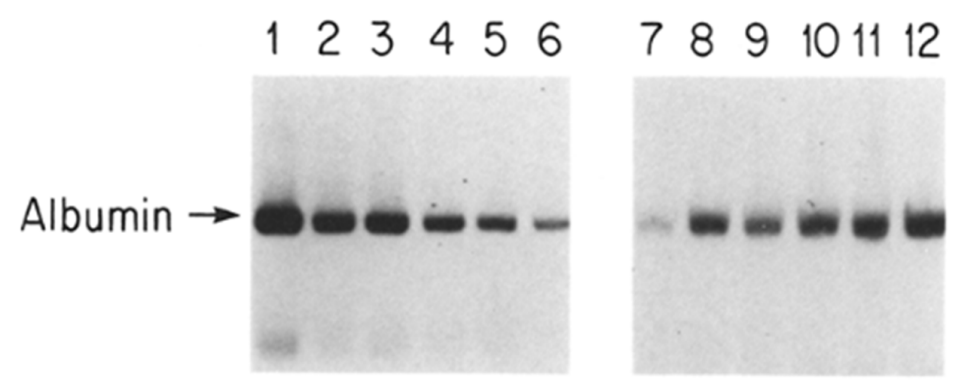

FIGURE 4. Kinetics of mouse recombinant IL-1 inhibition of $(A)$ albumin synthesis and kinetics of release, from $(B)$ the IL-1 effect. SDS-PAGE $(7.5 \%)$ of secreted $\left[{ }^{35} \mathrm{~S}\right]$ methioninelabeled albumin immunoprecipitated from media of hepatocyte cultures after preincubation with mouse IL-1 (100 U/ml). A 1, control (medium alone); 2, recombinant IL-l during the 2h pulse-labelling period; 3 , after $3 \mathrm{~h} ; 4$, after $7 \mathrm{~h} ; 5$, after $12 \mathrm{~h}$; and 6 , after $24 \mathrm{~h}$ with recombinant IL-1. $B, 7$, hepatocytes were pulse-labeled for $2 \mathrm{~h}, 4 \mathrm{~h}$ after washing out recombinant IL-1; 8 , control (no IL-1 preincubation); $9,10 \mathrm{~h}$ after release from recombinant II.-1: 10. 10-h control: $11.22 \mathrm{~h}$ after release from IL-1: 12. 22-h control.

Figure 3. Autoradiograph of a SDS-PAGE-analysis of radioactively labelled albumin from the supernatants of hepatocytes treated with the first recombinant IL-1 for different time lengths (panel A). Panel B demonstrates that the inhibitory effect of IL-1 on albumin synthesis is reversible (kinetic of release of the effect of the cytokine). J Exp Med 185;168:930-42. (reprinted with permission) ${ }^{[49]}$

of the large and small bowel ${ }^{[47,48]}$. The liver, as the source of the majority of the serum proteins, is the main target of the acute phase cytokines. These cytokines induce pretranslational modification of gene expression through direct interaction with the hepatocytes ${ }^{[4]}$ [Figure 3]. There are positive and negative acute phase $\operatorname{proteins}^{[45]}$.

According to the variations of their serum level, the positive acute-phase proteins are defined "major", not because of the volume of their serum level, but because of the magnitude (up to 1.000 fold) of the increase in their serum level.

CRP, Serum Amyloid A, Serum Amyloid P, lactoferrin ${ }^{[50]}$, Lipocalin- $2^{[51]}$, hepcidin ${ }^{[52-55]}$, Interleukin- ${ }^{[56]}$, and Erythropoietin ${ }^{[57]}$ all belong to the "major" acute-phase secretory protein group, while hemoxygenase-1 belongs to the positive ${ }^{[58]}$ intracellular acute-phase proteins. "Minor" acute-phase proteins are fibrinogen, fibronectin, ceruloplasmin, alpha-1-antitrypsin, complement fraction 3, Factor B, and many others.

As most of the major acute-phase proteins have a low molecular weight, measurement of their serum level may not correspond to a real increase in hepatic synthesis. This is due to the rapid elimination via the urine. Hepcidin was first identified in the urine ${ }^{[59]}$.

Albumin is the main negative secretory acute phase protein [Figure 4] ${ }^{[49]}$, whilst ferroportin-1 and hemojuvelin belong to the negative intracellular acute-phase protein group ${ }^{[52-55]}$. In a rat model, albumin mRNA in the liver was reduced by $50 \%$, while total mRNA was increased by $50 \%, 2$ days after infection with live Escherichia Coli ${ }^{[60]}$. During the 2 days rats ate only $5 \%-10 \%$ of the amount of food consumed prior to injection by the bacteria. This was followed by a further aggravation of the reduction of albumin synthesis ${ }^{[00]}$, further demonstrated in isolated liver perfusion studies ${ }^{[61]}$, and in humans under caloric restriction ${ }^{[62]}$. The amount of the acute-phase cytokines released into the circulation, and the concentration needed for the systemic appearance of the symptoms and of the metabolic changes, are different in different patients. They may be regulated differently by the drug administered, especially in the acute diseases. However, the response is mainly proportional to the extent of the tissue damage. 

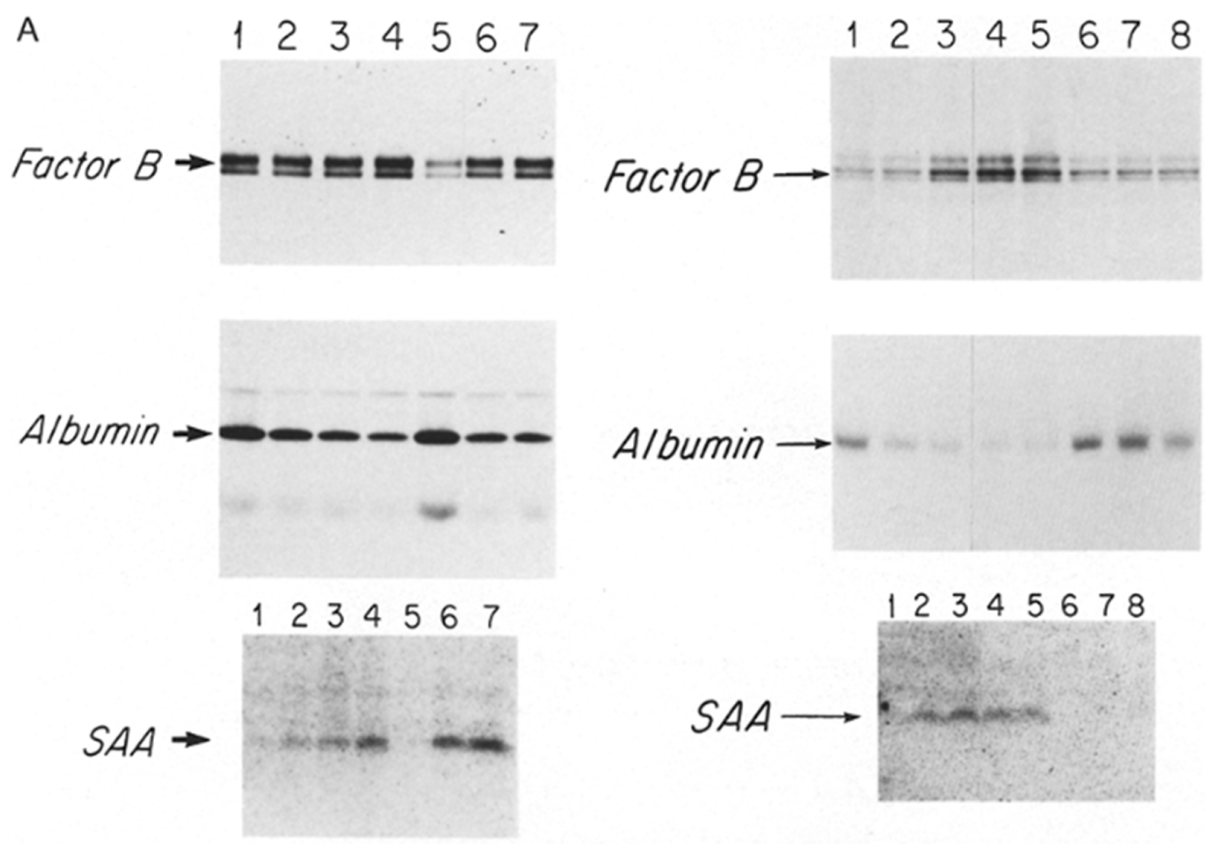

FIGURE 6. A, dose-response regulation of factor $\mathrm{B}$, albumin and SAA synthesis by hepatocytes in culture. SDS-PAGE ( $7.5 \%$ for albumin and factor B, $15 \%$ for SAA) of extracellular factor $\mathrm{B}$, albumin, and SAA immunoprecipitated from hepatocyte culture media, after a 2-h pulse with $\left[{ }^{35} \mathrm{~S}\right]$ methionine. Lanes $1-4,0.5,2.5,5.0$, and $10 \mathrm{U} / \mathrm{ml}$ human $\mathrm{IL}-1$, lane 5 , negative control (medium lacking human IL-1), 6 and 7, 10, and $40 \mathrm{U} / \mathrm{ml}$ of mouse recombinant IL-1, respectively. $B$, factor $\mathrm{B}$, albumin, and SAA biosynthesis by hepatocytes in culture; doseresponse to mouse recombinant 1 L-1. SDS-PAGE $(7.5 \%$ for albumin and for factor $B, 15 \%$ for SAA) of intracellular factor B, albumin, and SAA immunoprecipitated from cellular lysates after 22-h pulse with ${ }^{35}$ S $]$ methionine. Lane 1 , hepatocytes incubated with medium alone; 2 4 , hepatocytes incubated with medium containing $5,20,100 \mathrm{U} / \mathrm{ml}$ mouse recombinant IL-1; $5,30 \mathrm{U} / \mathrm{m}$ l human IL-1; 6 , nontransformed bacterial extract; 7 , medium containing dilution of guanidine hydrochloride; 8 , medium containing $10 \mu \mathrm{g} \mathrm{LPS} / \mathrm{ml}$. Film exposed $2 \mathrm{~d}$ for factor B, $24 \mathrm{~h}$ for albumin, and $21 \mathrm{~d}$ for SAA. The triplet of intracellular factor B represents different stages of glycosylation of the molecule.

Figure 4. Autoradiographs of SDS-PAGE-analysis of a biosynthetically, radio-actively labelled major positive acute-phase-protein (SAA), a minor positive acute-phase (factor B) and of the major negative acute-phase protein (albumin) immunoprecipitated from the same sample of supernatant from hepatocyte cultures treated with different amounts of recombinant IL1. Line 5 in panel A and lines 7-9 are negative controls. The relative abundance of the different proteins released into the supernatant is demonstrated by the time of exposure of the film to the filter containing the immunoprecipitated radioactive protein. The shortest time of exposure time was for albumin ( $24 \mathrm{~h}$ ) and the longest was SAA (21 days). While synthesis of albumin was inhibited by increasing doses of human recombinant IL-1, synthesis of factor B and of SAA were increased at the same time in the hepatocyte reproducing the process taking place in the liver in vivo during an acute phase situation. It is understandable that the serum concentrations of the acute-phase cytokines produced at extrahepatic sites has to be quite high to induce changes of protein synthesis in the liver until these can become measurable. This is also the case for those proteins whose constitutive gene-expression is almost undetectable, as is the case for SAA or CRP in humans. SAA: serum amyloid A. 1985;162:930-42. (reprinted with permission) ${ }^{[49]}$

In summary, two main mechanisms act in reducing albumin serum concentration in patients with severe COVID-19-infection: (1) reduction in albumin synthesis due to reduced food intake; (2) inhibition of specific mRNA-synthesis in the hepatocellular nuclei induced by the direct interaction of the cell with the acute-phase cytokines.

The acute-phase cytokines induce up-regulation of gene-expression of several positive hepatic acute-phase proteins, and in extrahepatic organs ${ }^{[63]}$ [Figure 5], but the changes in serum level are influenced by their synthesis in liver cells ${ }^{[45]}$. This mechanism is not only active in cases of tissue damage caused by bacterial, but also by viral infections ${ }^{[64]}$. The order of magnitude of variations in the serum level of the acute-phase proteins caused by viral infections is lower than that induced by bacterial infections. 

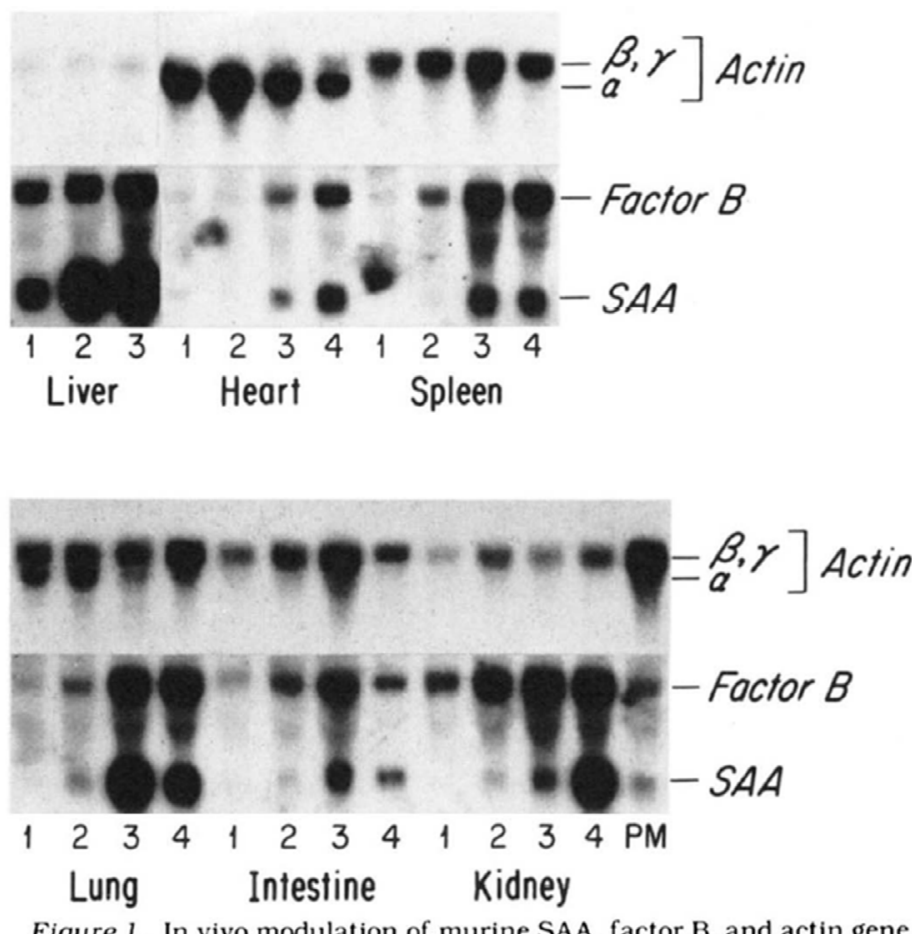

Figure 1. In vivo modulation of murine $\mathrm{SAA}$, factor $\mathrm{B}$, and actin gene expression by endotoxin. Animals ( $\mathrm{C} 3 \mathrm{HeB} / \mathrm{FeJ}$ mice) were killed and liver. heart, spleen. lung. intestine. and kidney were taken $16 \mathrm{hr}$ after injection of either saline (lane 1) or endotoxin at $1 \mu \mathrm{g}$ (lane 2), $10 \mu \mathrm{g}$ (lane 3), and $100 \mu \mathrm{g}$ (lane 4). $P M=$ RNA isolated $2 \mathrm{hr}$ after plating from peritoneal macrophages from five control animals. Fifteen micrograms of total RNA were loaded in each lane. Autoradiograms after exposure to Kodak XAR5 films at $24 \mathrm{hr}$ for the liver and 6 days for the other organs (SAA- and factor B-specific cDNA probes). and $6 \mathrm{hr}$ exposure for the actin-specific cDNA probe. The signals detected between lanes 1 and 2 of heart and in lane 1 of the spleen blots represent nonspecific background. This is one of three experiments that showed similar results. In all of the experiments. a dose-related effect of endotoxin on SAA and factor B gene expression was noted.

Figure 5. Autoradiograph of results of analysis of RNA (Northern) from organs of mice treated intraperitoneally with different amounts of E. Coli LPS as a model to induce an acute-phase reaction. The filters containing the tissue-RNA were hybridised with radio-actively labelled cDNAs specific for factor B, for SAA and for actin as control. In all organs factor B- and SAA-gene-expression was up-regulated in a dosedependent manner. The different time of exposure of the $x$-ray film demonstrate the different abundance of gene-expression of factor $B$ and SAA in the different organs. SAA: serum amyloid A; LPS: lipolysaccharide. J /mmuno/1985;135:3645-7. (reprinted with permission) ${ }^{[63]}$

Physical examination results obtained in hospitalized patients are not reported in the different publications, but most of the patients who were transferred from the emergency room to the ICU will likely have presented with clear signs of exsiccosis, hypotension and eventually malnutrition as testified by the low serum albumin levels. This should be highlighted in the guidelines for the initial supportive management of patients with COVID-19. If not recognized and promptly treated, progression to the second stage of the disease, with deterioration in respiratory function, will likely occur.

Patients suffering from mild disease who presented with normal serum albumin levels, even those who have developed a deterioration, maintained normal serum levels and could be released from the hospital ${ }^{[1,16,65]}$.

Although albumin administration is not recommended in patients with low serum albumin levels being treated in the $\mathrm{ICU}^{[35,36]}$, previous positive experiences ${ }^{[66]}$ with repeated administration of $200-400 \mathrm{~mL}$ of convalescent plasma showed positive effects in some critically ill COVID-19-patients ${ }^{[67-70]}$. The positive effect of convalescent plasma infusion could be attributed not only to the COVID-19-specific immunoglobulins, but also to the other components of the plasma e.g., albumin $^{[7]]}$. 


\section{DECLARATIONS}

\section{Authors' contributions}

The author contributed solely to the article.

\section{Availability of data and materials}

Not applicable.

\section{Financial support and sponsorship}

None.

\section{Conflicts of interest}

The author declared that there are no conflicts of interest.

\section{Ethical approval and consent to participate}

Not applicable.

\section{Consent for publication}

Not applicable.

\section{Copyright}

(C) The Author(s) 2020.

\section{REFERENCES}

1. Wang Y, Li X, Liu W, Gan M, Zhang L, et al. Discovery of a subgenotype of human coronavirus NL63 associated with severe lower respiratory tract infection in China, 2018. Emerg Microbes Infect 2020;9:246-55.

2. Zhou F, Yu T, Du R, Fan G, Liu Y, et al. Clinical course and risk factors for mortality of adult inpatients with COVID-19 in Wuhan, China: a retrospective cohort study. Lancet 2020;395:1054-62.

3. Huang C, Wang Y, Li X, Ren L, Zhao J, et al. Clinical features of patients infected with 2019 novel coronavirus in Wuhan, China. Lancet 2020;395:497-506.

4. Shi H, Han X, Jiang N, Cao Y, Alwalid O, et al. Radiological findings from 81 patients with COVID-19 pneumonia in Wuhan, China: a descriptive study. Lancet Infect Dis 2020;20:425-34.

5. Chen T, Wu D, Chen H, Yan W, Yang D, et al. Clinical characteristics of 113 deceased patients with coronavirus disease 2019: retrospective study. BMJ 2020;368:m1091.

6. Wang D, Hu B, Hu C, Zhu F, Liu X, et al. Clinical Characteristics of 138 Hospitalized Patients With 2019 Novel Coronavirus-Infected Pneumonia in Wuhan, China. JAMA 2020;323:1061-9.

7. Zhu N, Zhang D, Wang W, Li X, Yang B, et al. A novel coronavirus from patients with pneumonia in China, 2019. N Engl J Med 2020;382:727-33.

8. Li Q, Guan X, Wu P, Wang X, Zhou L, et al. Early transmission dynamics in Wuhan, China, of novel coronavirus-infected pneumonia. N Engl J Med 2020;382:1199-1207.

9. Liu Y, Yang Y, Zhang C, Huang F, Wang F, et al. Clinical and biochemical indexes from 2019-nCoV infected patients linked to viral loads and lung injury. Sci China Life Sci 2020;63:364-74.

10. Zhang Y, Xiao M, Zhang S, Xia P, Cao W, et al. Coagulopathy and antiphosphlipid antibodies in Patients with COVID-19. N Engl J Med 2020;382:e38.

11. Liu CL, Lu YT, Peng MJ, Chen PJ, Lin RL, et al. Clinical and laboratory features of severe acute respiratory syndrome vis-a-vis onset of fever. Chest 2004;126:509-17.

12. Leong HN, Earnest A, Lim HH, Chin CF, Tan C, et al. SARS in Singapore--predictors of disease severity. Ann Acad Med Singapore 2006;35:326-31.

13. Ko JH, Park GE, Lee JY, Lee JY, Cho SY, et al. Predictive factors for pneumonia development and progression to respiratory failure in MERS-CoV infected patients. J Infection 2016;73:468-75.

14. Leem AY, Park B, Kim YS, Jung JY, Won S. Incidence and risk of chronic obstructive pulmonary disease in a Korean community-based cohort. Int J Chron Obstruct Pulmon Dis 2018;13:509-17.

15. Zhang J, Wang X, Jia X, Li J, Hu K, et al. Risk factors for disease severity, unimprovement, and mortality in COVID-19 patients in Wuhan, China. Clin Microbiol Infect 2020; Epub ahead of print. doi: 10.1016/j.cmi.2020.04.012.

16. Gong J, Ou J, Qiu X, Jie Y, Chen Y, et al. A tool to early predict severe corona virus disease 2019 (COVID-19) : a multicenter study using 
the risk nomogram in Wuhan and Guangdong, China. Clin Infect Dis 2020; Epub ahead of print. doi: 10.1093/cid/ciaa443.

17. Cohn EJ, Oncley JL, Strong LE, Hughes WL, Armstrong SH. Chemical, clinical, and immunological studies on the products of human plasma fractionation. I. the characterization of the protein fractions of human plasma. J Clin Invest 1944;23:417-32.

18. Scatchard G, Batchelder AC, Brown A. Chemical,clinical and immunological studies on the products of human plasma fractonation. VI. The osmotic pressure of plasma and of serum albumin. J Clin Investt 1944;23:458-64.

19. Post J, Patek AJ. Serum proteins in relation to liver disorders. Bull N Y Acad Med 1943;19:815-30.

20. Thorn GW, Armstrong SH, Davemport VD. Chemical, clinical, and immunological studies on the products of human plasma fractionation. XXXI. The use of salt-poor concentrated human serum albumin solution in the treatment of hepatic cirrhosis. J Clin Invest 1946;25:30423.

21. Kunkel HG, Labby DH, Ahrens EH, Shank RE, Hoagland CL. The use of concentrated human serum albumin in the tretment of cirrhosis oft he liver. J Clin Invest 1948;27:305-19.

22. Wilkinson P, Sherlock S. The effect of repeated albumin infusions in patients with cirrhosis. Lancet 1962;2:1125-9.

23. Gentilini P, Casini-Raggi V, Di Fiore G, Romanelli RG, Buzzelli G, et al. Albumin improves the response to diuretics in patients with cirrhosis and ascites: results of a randomized, controlled trial. J Hepatol 1999;30:639-45.

24. Caraceni P, Riggio O, Angeli P, Alessandria C, Neri S, et al. Long-term albumin administration in decompensated cirrhosis (ANSWER):an open label randomized trial. Lancet 2018;391:2417-29.

25. Patek AJ, Mankin H, Colcher H, Lowell A, Earle DP. The effects of intravenous injection of concentrated human serum albumin upon blood plasma,ascites and renal functions in three patients with cirrhosis oft he liver. J Clin Invest 1948;27:135-44.

26. Schindler C, Ramadori G. Albumin substitution improves urinary sodium excretion and diuresis in patients with liver cirrhosis and refractory ascites. J Hepatol 1999;31:1132.

27. Schindler C, Ramadori G. Humanalbumingaben zur Verbesserung der renalen Ausscheidungsfunktion bei Patienten mit therapierefractärem Aszites-Ein Erfahrungsbericht. Leber Magen Darm 1999;4:183-7.

28. Nolte W, Ramadori G. Albumin for refractory ascites. Gastroenterology 2003;125:1283-4.

29. Trotter J, Pieramici E, Everson GT. Chronic albumin infusions to achieve diuresis in patients with ascites who are not candidates for transjugular intrahepatic portosystemic shunt(TIPS). Dig Dis Sci 2005;50:1356-60.

30. Bajaj JS, Tandon P, O’Leary JG, Biggins SW, Wong F, et al. The impact of albumin use on resolution of hyponatremia in hospitalized patients with cirrhosis. Am J Gastroenterol 2018;113:1339.

31. Bai Z, Bernardi M, Yoshida EM, Li H, Guo X, et al. Albumin infusion may decrease the incidence and severity of overt hepatic encephalopathy in liver cirrhosis. Aging (Albany NY) 2019;11:8502-25.

32. Kaplan DE, Dai F, Aytaman A, Baytarian M, Fox R, et al.; VOCAL Study Group. Development and performance of an algorithm to estimate the child-turcotte-pugh score from a national electronic healthcare database. Clin Gastroenterol Hepatol 2015;13:2333-41.e1-6.

33. Alberino F, Gatta A, Amodio P, Merkel C, Di Pascoli L, et al. Nutrition and survival in patients with liver cirrhosis. Nutrition 2001;17:445-50.

34. Paine CH, Biggins SW, Pichler RH. Albumin in cirrhosis: more than a colloid. Curr Treat Options Gastroenterol 2019;17:231-43.

35. Wujtewicz M, Dylczyk-Sommer A, Aszkiełowicz A, Zdanowski S, Piwowarczyk S, et al. COVID-19 - what should anaethesiologists and intensivists know about it? Anaesthesiol Intensive Ther 2020;52:34-41.

36. Alhazzani W, Møller MH, Arabi YM, Loeb M, Gong MN, et al. Surviving sepsis campaign:Guidelines on the management of critically ill adults with Coronavirus Disease 2019 (COVID-19). Intensive Care Med 2020;46:854-87.

37. Elmaouhoub A, Dudas J, Ramadori G. Kinetics of albumin- and alpha-fetoprotein-production during rat liver development. Histochem Cell Biol 2007;128:431-43.

38. Fanali G, di Masi A, Trezza V, Marino M, Fasano M, et al. Human serum albumin: from bench to bedside. Mol Aspects Med 2012;33:209-90.

39. Lin L, Jiang X, Zhang Z, Huang S, Zhang Z, et al. Gastrointestinal symptoms of 95 cases with SARS-CoV-2 infection. Gut 2020;69:9971001 .

40. Lechien JR, Chiesa-Estomba CM, De Siati DR, Horoi M, Le Bon SD, et al. Olfactory and gustatory dysfunctions as clinical presentation of mild-to-moderate forms of the coronavirus disease(COVID-19): a multicenter European study. Eur Arch Otorhinolaryngol 2020:1-11.

41. Lovato A, de Filippis C. Clinical presentation of COVID-19: a systematic review focusing on upper airway symptoms. Ear Nose Throat J 2020:145561320920762.

42. Russell B, Moss C, Rigg A, Hopkins C, Papa S, et al. Anosmia and ageusia are emerging as symptoms in patients with COVID-19: what does the current evidence say? Ecancermedicalscience 2020;14:ed98.

43. Baker T, Schell CO, Petersen DB, Sawe H, Khalid K, et al. Essential care of critical illness must not be forgotten in the COVID-19 pandemic. Lancet 2020;395:1253-4.

44. Dreher M, Kersten A, Bickenbach J, Balfanz P, Hartmann B, et al. Charakteristik von 50 hospitalisierten COVID-19-Patienten mit und ohne ARDS. Deutch Arztebl Int 2020;117:271-8.

45. Ramadori G, Christ B. Cytokines and the hepatic acute-phase response. Semin Liver Dis 1999;19:141-55.

46. Buckley MM, O’Brien R, Devlin M, Creed AA, Rae MG, et al. Leptin modifies the prosecretory and prokinetic effects of the inflammatory cytokine interleukin-6 on colonic function in Sprague-Dawley rats. Exp Physiol 2016;101:1477-91.

47. Goto J, Matsuda K, Harii N, Moriguchi T, Yanagisawa M, et al. Usefulness of a real-time bowel sound analysis system in patients with severe sepsis (pilot study). J Artif Organs 2015;18:86-91.

48. Groves HT, Higham SL, Moffatt MF, Cox MJ, Tregoning JS. Respiratory Viral Infection Alters the Gut Microbiota by Inducing 
Inappetence. mBio 2020;11:e03236-19.

49. Ramadori G, Sipe JD, Dinarello CA, Mizel SB, Colten HR. Pretranslational modulation of acute phase hepatic protein synthesis by murine recombinant interleukin 1 (IL-1) and purified human IL-1. J Exp Med 1985;162:930-42.

50. Ahmad G, Sial GZ, Ramadori P, Dudas J, Batusic DS, et al. Changes of hepatic lactoferrin gene expression in two mouse models of the acute phase reaction. Int J Biochem Cell Biol 2011;43:1822-32.

51. Sultan S, Pascucci M, Ahmad S, Malik IA, Bianchi A, et al. LIPOCALIN-2 is a major acute-phase protein in a rat and mouse model of sterile abscess. Shock 2012;37:191-6.

52. Sheikh N, Dudas J, Ramadori G. Changes of gene-expression of iron regulatory proteins during turpentin-oil induced acute-phase response in the rat. Lab Invest 2007;87:713-25.

53. Sheikh N, Batusic DS, Dudas J, Tron K, Neubauer K, et al. Hepcidin and hemojuvelin gene expression in rat liver damage: in vivo and in vitro studies. Am J Physiol Gastrointest Liver Physiol 2006;291:G482-90.

54. Christiansen H, Sheikh N, Saile B, Reuter F, Rave-Fränk M, et al. x-Irradiation in rat liver: consequent upregulation of hepcidin and downregulation of hemojuvelin and ferroportin-1 gene expression. Radiology 2007;242:189-97.

55. Moriconi F, Ahmad G, Ramadori P, Malik I, Sheikh N, et al. Phagocytosis of gadolinium chloride or zymosan induces simultaneous upregulation of hepcidin- and downregulation of hemojuvelin- and Fpn-1-gene expression in murine liver. Lab Invest 2009;89:1252-60.

56. Sheikh N, Tron K, Dudas J, Ramadori G. Cytokine-induced neutrophil chemoattractant-1 is released by the noninjured liver in a rat acutephase model. Lab Invest 2006;86:800-14.

57. Ramadori P, Sheikh N, Ahmad G, Dudas J, Ramadori G. Hepatic changes of erythropoietin gene expression in a rat model of acute-phase response. Liver Int 2010;30:55-64.

58. Tron K, Novosyadlyy R, Dudas J, Samoylenko A, Kietzmann T, et al. Upregulation of heme oxygenase-1 gene by turpentine oil-induced localized inflammation: involvement of interleukin-6. Lab Invest 2005;85:376-87.

59. Krause A, Neitz S, Mägert HJ, Schulz A, Forssmann WG, et al. LEAP-1, a novel highly disulfide-bonded human peptide, exhibits antimicrobial activity. FEBS Lett 2000;480:147-50.

60. Ruot B, Breuillé D, Rambourdin F, Bayle G, Capitan P, et al. Synthesis rate of plasma albumin is a good indicator of liver albumin synthesis in sepsis. Am J Physiol Endocrinol Metab 2000;279:E244-51.

61. Flaim KE, Liao WS, Peavy DE, Taylor JM, Jefferson LS. The role of amino acids in the regulation of protein synthesis in perfused rat liver. II. Effects of amino acid deficiency on peptide chain initiation, polysomal aggregation, and distribution of albumin mRNA. J Biol Chem 1982;257:2939-46.

62. Lee JL, Oh ES, Lee RW, Finucane TE. Serum albumin and prealbumin in calorically restricted, nondiseased individuals: a systematic review. Am J Med 2015;128:1023.e1-22.

63. Ramadori G, Sipe JD, Colten HR. Expression and regulation of the murine serum amyloid A (SAA) gene in extrahepatic sites. J Immunol 1985;135:3645-7.

64. Perez L. Acute phase protein response to viral infection and vaccination. Arch Biochem Biophys 2019;671:196-202.

65. Zhou Y, Zhang Z, Tian J, Xiong S. Risk factors associated with disease progression in a cohort of patients infected with the 2019 novel coronavirus. Ann Palliat Med 2020;9:428-36.

66. Chen L, Xiong J, Bao L, Shi Y. Convalescent plasma as a potential therapy for COVID-19. Lancet Infect Dis 2020;20:398-400.

67. Shen C, Wang Z, Zhao F, Yang Y, Li J, et al. Treatment of 5 critically ill patients with COVID-19 with convalescent plasma. JAMA 2020;323:1582-9.

68. Duan K, Liu B, Li C, Zhang H, Yu T, et al. Effectivness of convalescent plasma therapy in severe COVID-19 patients. Proc Natl Acad Sci 2020;117:9490-6.

69. Zhang B, Liu S, Tan T, Huang W, Dong Y, et al. Treatment with convalescent plasma for critically ill patients with SARS-CoV-2 infection. Chest 2020; Epub ahead of print. doi: 10.1016/j.chest.2020.03.039.

70. Bloch EM, Shoham S, Casadevall A, Sachais BS, Shaz B, et al. Deployment of convalescent plasma fro prevention and treatment of COVID-19. J Clin Invest 2020; Epub ahead of print. doi: 10.1172/JCI138745.

71. Roback JD, Guarner J. Convalescent plasma to treat COVID-19: possibilities and challenges. JAMA. 2020; Epub ahead of print. doi: 10.1001/jama.2020.4940. 